level on the lines of the recent arrangements on sugar and cocoa, or be restricted to the EEC and the interested developing countries. Precedents to such agreements are the Commonwealth Sugar Agreement and the GATT LTA on Cotton Textiles. It might be feasible for the enlarged Community to conclude special agreements either with the Commonwealth countries as a whole or with all interested developing countries with respect to such products as sugar, jute and coir products, coconut and palm oil, and preserved fruit and vegetables. If satisfactory arrangements could be made ensuring adequate access for the main exports adversely affected by the enlargement of the Community, this could take care of some of the more urgent problems likely to be faced by the Asian Commonwealth countries.

To ease the problem of adjustment, the transitional measures could be applied in a more generous manner. One approach would be to delay the unification of the external tariff of the UK with respect to A sian Commonwealth countries until such time as alternative trade arrangements have been negotiated, as is intended for the associable countries. Should this not prove feasible, the unification of the common external tariff should be interpreted to mean that tariffs on imports from the Asian Commonwealth countries would be adjusted upwards gradually to the Community level and not apply the UK mfn rates to them at the time of the first move towards alignment with the common tariff.

Either in addition to or in substitute of some of the measures suggested above, the Asian Commonwealth countries affected adversely by the British entry into EEC, could be offered additional financial and technical assistance to compensate for the losses incurred. This assistance should ideally be given in an united form. However, in specific cases, it might be tied to diversification programmes or market development in the EEC where products adversely affected are uncompetitive in world markets.

\title{
VII. SOME IMPLICATIONS FOR DEVELOPMENT ASSISTANCE
}

Although this study is concerned primarily with trade, the enlargement of the EEC will also have some implications for development assistance. In the first place, starting in 1975, Britain and other new members of the EEC will be required to contribute to the European Development Fund (EDF). The share of total development assistance channelled by the members of the European Community through the EDF has been relatively modest, though it has arisen from 0.6 per cent in 1965 to 5.8 per cent in 1970 . France and Germany disbursed a total of $\$$ US $43.9 \mathrm{~m}$. each through the EDF in 1970 . It is likely that Britain would have been expected to contribute a similar a mount had she been a member then. For purposes of comparison, it may be noted that net flows of official development assistance from UK to 
developing countries and multilateral agencies amounted to US $\$ 447 \mathrm{~m}$. in 1970. Thus the British contribution to the EDF would have amounted to nearly 10 per cent of its total aid programme.

On the basis of the past trends and the declared policy of the EEC, it seems a reasonable assumption to make that the share of aid going through the EDF will continue to rise in the future and that the necessary adjustments will be made to take account of increase in the number of associated countries. This, therefore, means that a certain proportion of British aid, say between 10 to 15 per cent. ${ }^{1}$ It has not been possible to estimate with any precision what proportion of British total aid would be channelled through the EDF. However, it is reasonable to expect that such a proportion would be influenced both by the number of Commonwealth "associables" likely to benefit from the Fourth EDF facility and on the British View of the merits of multilateral as against bilateral aid will be earmarked in the period 1975 to 1980 for disbursement through the EDF. Even if the current bilateral aid given to the associable countries is adjusted after their association with the EEC, it is reasonable to expect some diversion of the British aid to the Yaounde countries, since this is negligible at the moment. It may, therefore, be concluded that the relative if not the absolute amount of British aid going to the ACCs will be adversely affected by the enlargement of the EEC. Since Britain has been a significant source of development assistance to these countries, the overall effect could be considerable. This may be further reinforced by a similar shift of aid from the Six in favour of the associable Commonwealth developing countries should they decide to seek association.

\section{SUMMARY OF MAIN FINDINGS AND RECOMMENDATIONS}

(1) A study of the pattern and trends of trade of the Asian Commonwealth countries (ACCs) in the sixties indicates a steady decline in the importance of UK as an export market. On the other hand, the importance of Japan, the USSR and the USA has risen in most cases. The relative importance of the UK and the Six as export markets for these countries is shown below for 1970 :

1 It has not been possible to estimate with any precision what proportion of British total aid would be channelled through the EDF. However, it is reasonable to expect that such a proportion would be influenced both by the number of Commonwealth "associables" likely to benefit from the Fourth EDF facility and on the British view of the merits of multilateral as against bilateral aid. 